\title{
Genetic Analysis of Variability and Divergence in French Bean (Phaseolus vulgaris L.)
}

\author{
A. Panda ${ }^{1 *}$, A. Paul ${ }^{2}$ and P. Mohapatra ${ }^{3}$ \\ ${ }^{1 \& 2}$ Dept. of CIHAB, Palli Siksha Bhavana (Institute of Agriculture), Visva-Bharati, Sriniketan, \\ West Bengal (731 236), India \\ ${ }^{3}$ Dept. of Vegetable Science, O.U.A.T., Bhubaneswar, Odisha (751 003), India
}

\section{Article History}

Manuscript No. AR1505

Received in $22^{\text {nd }}$ December, 2015

Received in revised form $28^{\text {th }}$ June, 2016

Accepted in final form $25^{\text {th }}$ July, 2016

\section{Correspondence to}

"E-mail: amitabhp70@gmail.com

\section{Keywords}

Genetic variability, diversity, french bean, $\mathrm{D}^{2}$, heretability

\begin{abstract}
Field experiments were conducted during two consecutive rabi seasons i.e. 2011-12 and 2012-13 in four locations of district Nayagarh in Odisha to evaluate 28 genotypes of French bean for 13 morphological traits. The per se performance of genotypes showed that HAFB-1 ranked first for 6 out of 13 characters. Combined analysis of GCV, heritability and genetic advance showed that the traits such as plant height, number of pods plant ${ }^{-1}$ and number of secondary branches plant ${ }^{-1}$ would respond effectively for phenotypic selection. The $\mathrm{D}^{2}$ analysis grouped the genotypes into 7 clusters, out of which 2 were mono-genotypic cluster. There was grouping of genotypes of diverse origin into single cluster. The inter-cluster distance values were more than intra-cluster values suggesting more heterogeneity among clusters. Clusters VII, V, IV, VI were found to be highly divergent than rest of the clusters. So crosses among the clusters may be taken for producing superior genotypes. The cluster-IV showed high mean values for pod yield, single pod weight, number of podsplant ${ }^{-1}$, green pod breadth, number of primary and secondary branches plant ${ }^{-1}$, whereas Cluster-V recorded high green pod length and plant height. So the genotypes from both the cluster may be crossed to incorporate desirable traits. Plant height contributed maximum towards divergence. Cluster analysis on the basis of $\mathrm{D}^{2}$ was correlated with canonical analysis. Pooled analysis of variability and divergence showed that the genotypes HAFB-1, HAFB-5, HAFB-6, PDR-14, IIHR-4 may be included in hybridization programme for producing superior genotypes and wide segregants in fillial generations.
\end{abstract}

\section{Introduction}

French bean (Phaseolus vulgaris L. Fabaceae) is an annual herbaceous self-pollinated plant $(2 n=2 X=22)$. It is native to Mexico, Central America and North Andes of South America (Kaplan, 1965). It has one of the longest histories of cultivated plants and is widely cultivated in the temperate and subtropical regions and in many parts of the tropics. It originated from a wild form, of which P. aborigineus is a modern survivor (Evans, 1976). It is the most important legume for human consumption (Singh, 1999). The statistics with respect to this crop is very poor owing to its short duration and cultivation in limited areas. However, as per FAO estimates, it is cultivated in an area of 28 mha, with annual production of $20 \mathrm{mt}$, with average productivity of $0.72 \mathrm{t} \mathrm{ha}^{-1}$ in world (FAOSTAT, 2008). In India, it is mainly grown in Jharkhand, Maharashtra, Karnataka, West Bengal, Himachal Pradesh, Odisha, Uttar Pradesh, Punjab, Haryana, Andhra Pradesh,
Tamil Nadu in an area of 0.15 mha with annual production of $0.42 \mathrm{mt} 42 \mathrm{mt}$ and productivity of $2.8 \mathrm{t} \mathrm{ha}^{-1}$ compared to China $\left(26 \mathrm{t} \mathrm{ha}^{-1}\right)(\mathrm{FAO}, 2002)$. In Odisha, it is cultivated in $11.01^{\prime} 000$ ha area, production $50.9^{\prime} 000 \mathrm{mt}$, productivity 4.52 $\mathrm{t} \mathrm{ha}^{-1}$ (Anonymous, 2012).

French bean otherwise called as "the meat of the poor" provides a wide range of variability, diversity with a tremendous scope for genetic studies and improvement. Information on the genetic variability is an important requirement for realizing response to selection. It is essential to differentiate between genetic and non-genetic component of variability before selection. Diversity in the genotypes is essential in order to create variability. Further, selection of parents for the purpose of breeding depends upon the existence of genetic diversity and its assessment is very much helpful in improvement of quantitative traits (Govankoppa et al., 2002). Intercrossing between more divergent parents is expected to generate a broad spectrum of variability and selection can be adopted 
in segregating generations. In this regard, $\mathrm{D}^{2}$ statistics has been extensively used to measure the genetic divergence in breeding programmes. Hence an attempt was made to assess the degree of variability and magnitude of genetic divergence in French bean genotypes and to identify genetically divergent parents, which can be utilized in a hybridization programme.

\section{Materials and Methods}

The present investigation was undertaken during two consecutive rabi seasons of 2011 and 2012 at four locations of district Nayagarh $\left(20^{\circ} 24^{\prime} \mathrm{N}, 85^{\circ} 12^{\prime} \mathrm{E}, 90 \mathrm{~m}\right.$ amsl $)$ under east and south eastern coastal plain zone in Odisha. The experimental material comprised of twenty eight genotypes of French bean consisting of released and pre-released lines obtained from five states of India. The experiment was laid out in a randomized block design with three replications in each of the four environments over both the growing seasons. The seeds of each genotype were sown on 2 rows of $3 \mathrm{~m}$. long keeping plant to plant and row to row spacing of $15 \mathrm{~cm}$. and $50 \mathrm{~cm}$. respectively in the month of November. All the recommended package of practices was followed during the crop season for raising a healthy crop. Harvesting of pods was done at tender stage in three pickings.

The data on horticultural traits like days to $50 \%$ flowering, days to $1^{\text {st }}$ green pod picking, plant height $(\mathrm{cm})$, number of primary branches plant ${ }^{-1}$, number of secondary branches plant $^{-1}$, basal internodal length $(\mathrm{cm})$, basal internodal diameter $(\mathrm{cm})$, green pod length $(\mathrm{cm})$, green pod width $(\mathrm{cm})$, green pod breadth $(\mathrm{cm})$, number of pods plant ${ }^{-1}$, single pod weight $(\mathrm{g})$, pod yield plant ${ }^{-1}(\mathrm{~g})$ were recorded using standard procedures. Genetic diversity was studied using $\mathrm{D}^{2}$ statistics of Mahalanobis (1936) and populations were grouped into clusters by following the method as suggested by Rao (1952). Canonical analysis was done following Rao (1952).

\section{Results and Discussion}

\subsection{Genetic variability, heritability and genetic advance}

Analysis of variance revealed significant differences among the genotypes of French bean for all the studied traits except green pod width and green pod breadth.

The mean values of top five ranking genotypes for all the thirteen studied traits are given (Table 1). It showed that the genotype HAFB-1 exhibited highest values for six out of thirteen traits i.e. number of primary branches plant ${ }^{-1}$, number of secondary branches plant ${ }^{-1}$, green pod length, green pod breadth, single pod weight, pod yield plant plant ${ }^{-1}$ and second highest values for number of pods plant ${ }^{-1}$. The second in the rank, HAFB-5 stood first for number of pods plant ${ }^{-1}$ and days to $50 \%$ flowering (minimum value). The third genotype HAFB-6 also exhibited good performance for number of primary branches plant $^{-1}$, number of secondary branches

\begin{tabular}{|c|c|c|c|c|c|c|c|c|c|c|c|c|c|}
\hline Rank & DFF & $\begin{array}{l}\text { DFG } \\
\text { GPP }\end{array}$ & $\begin{array}{l}\mathrm{PH} \\
(\mathrm{cm})\end{array}$ & NPBP & NSBP & $\begin{array}{l}\text { BIL } \\
(\mathrm{cm})\end{array}$ & $\begin{array}{l}\text { BID } \\
(\mathrm{cm})\end{array}$ & $\begin{array}{l}\text { GPL } \\
(\mathrm{cm})\end{array}$ & $\begin{array}{l}\text { GPW } \\
(\mathrm{cm})\end{array}$ & $\begin{array}{l}\text { GPB } \\
(\mathrm{cm})\end{array}$ & NPP & $\begin{array}{c}\text { SPW } \\
(\mathrm{g})\end{array}$ & $\begin{array}{c}\text { PYP } \\
(\mathrm{g})\end{array}$ \\
\hline 1. & $\begin{array}{c}\text { HAFB- } \\
5\end{array}$ & $\begin{array}{l}\text { FAB } \\
\text { Var-6 }\end{array}$ & $\begin{array}{c}\text { Swa- } \\
\text { rna } \\
\text { Lata }\end{array}$ & $\begin{array}{c}\text { HAFB } \\
-1\end{array}$ & $\begin{array}{c}\text { HAFB } \\
-1\end{array}$ & $\begin{array}{c}\text { HAFB } \\
-4\end{array}$ & $\begin{array}{c}\text { Arka } \\
\text { Anoop }\end{array}$ & $\begin{array}{c}\text { HAFB } \\
-1\end{array}$ & $\begin{array}{c}\text { HAFB } \\
-6\end{array}$ & $\begin{array}{c}\text { HAFB } \\
-1\end{array}$ & $\begin{array}{c}\text { HAFB } \\
-5\end{array}$ & $\begin{array}{c}\text { HAFB } \\
-1\end{array}$ & $\begin{array}{c}\text { HAFB } \\
-1\end{array}$ \\
\hline 2. & $\begin{array}{c}\text { HUR } \\
-137\end{array}$ & $\begin{array}{c}\text { HAFB } \\
-5\end{array}$ & $\begin{array}{c}\text { HAFB } \\
-4\end{array}$ & $\begin{array}{c}\text { HAFB } \\
-6\end{array}$ & $\begin{array}{c}\text { HAFB } \\
-6\end{array}$ & $\begin{array}{l}\text { Swa- } \\
\text { rna } \\
\text { Lata }\end{array}$ & $\begin{array}{c}\text { HAFB } \\
-1\end{array}$ & $\begin{array}{c}\text { Arka } \\
\text { Suvi- } \\
\text { dha }\end{array}$ & $\begin{array}{c}\text { FB- } \\
53\end{array}$ & $\begin{array}{c}\text { HAFB } \\
-5\end{array}$ & $\begin{array}{c}\text { HAFB } \\
-1\end{array}$ & $\begin{array}{c}\text { HAFB } \\
-6\end{array}$ & $\begin{array}{c}\text { HAFB } \\
-5\end{array}$ \\
\hline 3. & $\begin{array}{c}\text { FAB } \\
\text { Var-3 }\end{array}$ & $\begin{array}{c}\text { HAFB } \\
-1\end{array}$ & $\begin{array}{c}\text { HAFB } \\
-1\end{array}$ & $\begin{array}{c}\text { Arka } \\
\text { Komal }\end{array}$ & $\begin{array}{c}\text { HAFB } \\
-5\end{array}$ & $\begin{array}{c}\text { HAFB } \\
-6\end{array}$ & $\begin{array}{c}\text { IIHR } \\
-4\end{array}$ & $\begin{array}{c}\text { Swar- } \\
\text { na } \\
\text { Lata }\end{array}$ & $\begin{array}{c}\text { Arka } \\
\text { Kom- } \\
\text { al }\end{array}$ & $\begin{array}{c}\text { HAFB } \\
-6\end{array}$ & $\begin{array}{c}\text { Kasi } \\
\text { Param }\end{array}$ & $\begin{array}{l}\text { Arka } \\
\text { Suvi } \\
\text {-dha }\end{array}$ & $\begin{array}{c}\text { HAFB } \\
-6\end{array}$ \\
\hline 4. & $\begin{array}{c}\text { HAFB } \\
-1\end{array}$ & $\begin{array}{c}\text { VL } \\
\text { Bean- } \\
1\end{array}$ & $\begin{array}{c}\text { HAFB } \\
-6\end{array}$ & $\begin{array}{c}\text { HAFB } \\
-4\end{array}$ & $\begin{array}{c}\text { Arka } \\
\text { Komal }\end{array}$ & $\begin{array}{c}\text { HAFB } \\
-1\end{array}$ & $\begin{array}{c}\text { HAFB } \\
-6\end{array}$ & $\begin{array}{c}\text { HAFB } \\
-5\end{array}$ & $\begin{array}{c}\text { Arka } \\
\text { Suvi- } \\
\text { dha }\end{array}$ & $\begin{array}{c}\text { PDR } \\
-14\end{array}$ & $\begin{array}{c}\text { VL } \\
\text { Bean } \\
-2\end{array}$ & $\begin{array}{l}\text { FAB } \\
\text { Var-2 }\end{array}$ & $\begin{array}{c}\text { Arka } \\
\text { Komal }\end{array}$ \\
\hline 5. & $\begin{array}{c}\text { VL } \\
\text { Bean-1 }\end{array}$ & $\begin{array}{l}\text { FAB } \\
\text { Var-3 }\end{array}$ & $\begin{array}{c}\text { Arka } \\
\text { Anoop }\end{array}$ & $\begin{array}{c}\text { HAFB } \\
-5\end{array}$ & $\begin{array}{c}\text { VL } \\
\text { Bean- } \\
2\end{array}$ & $\begin{array}{c}\text { Arka } \\
\text { Anoop }\end{array}$ & $\begin{array}{c}\text { HAFB } \\
-5\end{array}$ & $\begin{array}{c}\text { HAFB } \\
-6\end{array}$ & $\begin{array}{c}\text { HAFB } \\
-5\end{array}$ & $\begin{array}{l}\text { Cont- } \\
\text { ender }\end{array}$ & $\begin{array}{c}\text { Arka } \\
\text { Komal }\end{array}$ & $\begin{array}{c}\text { Swa- } \\
\text { rna } \\
\text { Lata }\end{array}$ & $\begin{array}{c}\mathrm{VL} \\
\text { Bean } \\
-2\end{array}$ \\
\hline
\end{tabular}

DFF: Days to 50\% flowering; DFGGPP: Days to $1^{\text {st }}$ green pod picking; PH: Plant height; NPBP: No. of primary branches plant $^{-1}$; NSBP: No. of secondary branches plant ${ }^{-1}$; BIL: Basal inter nodal length; BID: Basal internodal diameter; GPL: Green pod length; GPW: Green pod width; GPB: Green pod breadth; NPP: No. of pods plant ${ }^{-1}$; SPW: Single pod weight; PYP: Pod yield plant ${ }^{-1}$ 
plant $^{-1}$ and single pod weight. The above three genotypes are considered suitable for cultivation.

Estimates of range, PCV, GCV, heritability (broad sense) and genetic advance (GA) as percent of means are given (Table 2). Considerable variability was observed for all the traits under study as indicated by high range indicating enough scope for bringing about improvement in the desired direction. PCV represents effect of heritable and non-heritable component, whereas GCV represents effect of heritable component alone. So, it would be more rewarding to lay emphasis on GCV rather than PCV (Johnson et al., 1955). In the present study, the traits such as plant height, number of secondary branches plant $^{-1}$, basal internodal diameter, number of green pods plant $^{-1}$, pod yield plant ${ }^{-1}$, basal internodal length showed high GCV values, Lal et al. (2005); Pan et al. (2004). So, selection for these traits would result in isolation of superior genotypes having these traits.

The GCV together with heritability estimates would give reliable indication of the expected amount of improvement through selection and therefore estimation of heritability is necessary. The characters such as green pod length, basal internodal diameter, days to $1^{\text {st }}$ green pod picking, plant height, basal internodal length, green pod width, number of pods plant ${ }^{-1}$, days to $50 \%$ flowering, number of secondary branches plant ${ }^{-1}$ showed very high amount of heritability. The results are in consonance with the findings obtained by Nimbalkar et al. (2002) for plant height, green pod length and number of pods plant ${ }^{-1}$ and Singh et al. (2000) for days to $50 \%$ flowering. Higher heritability value indicates lesser influence of environment, hence more desirable for selection.
Johnson et al. (1955) reported that the heritability estimate along with genetic advance is more useful than the heritability alone in predicting that resultant effect of selecting the best individual genotypes as it suggests the presence of additive effects (Panse and Sukhatme, 1985). The traits such as number of primary branches plant ${ }^{-1}$, green pod length, single pod weight, green pod width, days to $50 \%$ flowering, basal internodal diameter, number of secondary branches plant ${ }^{-1}$, plant height, number of pods plant ${ }^{-1}$, pod yield plant ${ }^{-1}$ and basal internodal length showed high genetic gain $(>20 \%)$. The results are in accordance with the findings of Nimbalkar (2002); Rai et al. (2006).

Combined analysis of GCV, heritability and genetic advance would give the extent of advance through selection (Burton, 1952). In the present study traits such as plant height $(\mathrm{GCV}=30.07, \mathrm{H} 2=85.34, \mathrm{GA} \%=51.67)$, number of pods plant $^{-1} \quad(\mathrm{GCV}=36.80, \mathrm{H} 2=81.58, \mathrm{GA} \%=58.50)$, number of secondary branches plant ${ }^{-1}(\mathrm{GCV}=22.11, \mathrm{H} 2=92.00$, $\mathrm{GA} \%=37.32$ ) showed high values for above parameters. It showed the greater scope for improvement of these traits by simple phenotypic selection. Similar findings were reported by Rai et al. (2004); Kalia and Pathania (2007) for number of pods plant ${ }^{-1}$. Earlier Johnson et al. (1955) had also reported that high GCV along with high heritability and genetic advance were more effective for selection of soyabean genotypes, which was in agreement with these findings.

\subsection{Divergence study}

Analysis of variance for divergence showed highly significant differences among the genotypes for all the thirteen traits studied. The genotypes were grouped into seven clusters

Table 2: Estimation of different parameters of variability, heritability and genetic advance under selection (at 5\%)

\begin{tabular}{|c|c|c|c|c|c|c|c|}
\hline Sl. no. & Characters & Range & $\begin{array}{c}\text { Grand } \\
\text { mean }\end{array}$ & $\begin{array}{l}\text { GCV } \\
(\%)\end{array}$ & $\begin{array}{l}\text { PCV } \\
(\%)\end{array}$ & $\begin{array}{l}\mathrm{H}^{2} \\
(\%)\end{array}$ & $\begin{array}{c}\text { GA as } \% \text { of } \\
\text { mean }\end{array}$ \\
\hline 1. & Days to $50 \%$ flowering & $31.14-55.59$ & 43.32 & 14.39 & 15.07 & 91.12 & 24.17 \\
\hline 2. & Days to $1^{\text {st }}$ green pod picking & $51.87-81.33$ & 64.62 & 11.07 & 11.91 & 86.42 & 18.11 \\
\hline 3. & Plant height & $35.94-121.76$ & 60.87 & 30.07 & 31.79 & 85.34 & 51.67 \\
\hline 4. & Number of primary branches plant ${ }^{-1}$ & $2.95-5.27$ & 3.88 & 15.12 & 18.17 & 69.21 & 22.13 \\
\hline 5. & Number of secondary branches plant $t^{-1}$ & $4.39-9.65$ & 6.56 & 22.11 & 23.05 & 92.00 & 37.32 \\
\hline 6. & Basal internodal length & $1.22-7.73$ & 2.38 & 61.26 & 66.80 & 84.12 & 98.89 \\
\hline 7. & Basal internodal diameter & $0.34-.81$ & 0.58 & 23.33 & 26.56 & 77.18 & 36.07 \\
\hline 8. & Green pod length & $10.17-17.74$ & 13.94 & 14.73 & 17.02 & 74.96 & 22.45 \\
\hline 9. & Green pod width & $0.51-1.02$ & 0.74 & 18.11 & 19.53 & 85.90 & 29.53 \\
\hline 10. & Green pod breadth & $0.87-1.22$ & 1.02 & 8.52 & 10.31 & 68.26 & 12.39 \\
\hline 11. & Number of pods plant ${ }^{-1}$ & $6.98-25.27$ & 14.20 & 36.80 & 38.69 & 81.58 & 58.50 \\
\hline 12. & Single pod weight & $4.67-9.39$ & 7.56 & 16.46 & 21.17 & 60.44 & 22.52 \\
\hline 13. & Pod yield plant ${ }^{-1}$ & $44.26-94.78$ & 95.22 & 39.80 & 46.34 & 73.76 & 60.16 \\
\hline
\end{tabular}


(Table 3). Among the clusters, maximum number of genotypes (9) were included in cluster I followed by cluster II (8), cluster III (4), cluster IV (3), cluster V (2). Cluster VI \& VII were monogenotypic cluster consisting of one genotype each indicating their independent identity and importance due to various unique characters possessed by them. The formation of largest cluster I comprising 9 genotypes might be due to a free flow (or) exchange of breeding material from one place to another (Suneetha et al., 2013). Dispersion pattern of cultivars over a large number of clusters with a maximum of 9 cultivars in cluster I to one cultivar in cluster VI and VII indicates the presence of maximum degree of divergence and genetic heterogeneity among cultivars.

Generally, the geographical diversity has been considered as a measure of genetic diversity. However, this is an inferential criterion and it may not be so effective in quantifying different populations. The present pattern of grouping of genotypes indicated that the genetic diversity was not fully associated with geographic diversity i.e. the genotypes have grouped or diverged into different clusters irrespective of their geographical origin which means that the genetic constitution of the varieties was more dominant than their geographical origin while forming a cluster (Choubey et al., 2003; Singh, 2006). This kind of genetic diversity was recorded among the genotypes belonging to the same geographic origin might be due to differences in adoption, selection pressure and selection criteria, and environmental condition (Gokul krishnan et al., 2012). Random genetic drift and selection exercised for specific characters in specified environments could cause greater diversity than geographical distance (Murthy and Arunachalam, 1966). Such a wide diversity among the genotypes of same geographic region is desirable for selecting parents with similar adaptability for

Table 3: Distribution of French bean genotypes in various clusters based on $\mathrm{D}^{2}$ analysis

\begin{tabular}{lcll}
\hline $\begin{array}{l}\text { Clus- } \\
\text { ters }\end{array}$ & $\begin{array}{c}\text { No. of } \\
\text { genotypes in } \\
\text { the cluster }\end{array}$ & \multicolumn{1}{c}{ Genotypes included in the cluster } & \multicolumn{1}{c}{ Source } \\
\hline I & 9 & $\begin{array}{l}\text { FAB Var-2, VL Bean-3, FAB Var-3,HAFB-2, } \\
\text { Pant Anupam, HAPB- 4, Almora local-1, Almora } \\
\text { local-2, VL bean-1 }\end{array}$ & $\begin{array}{l}\text { UAS, Dharwad, G.B.P.U.A.\&T, Pantnagar, } \\
\text { HARP, Ranchi, VPKAS, Almora }\end{array}$ \\
II & 8 & $\begin{array}{l}\text { FAB Var-6, HUR-137, FB-53,VL Bean-2, } \\
\text { Contender, Arka Anoop, Arka Suvidha, Arka }\end{array}$ & $\begin{array}{l}\text { UAS, Dharwad, VPKAS, Almora, IIHR, } \\
\text { Bangalore, IIVR Varanasi }\end{array}$ \\
& & Komal & HARP Ranchi, IIHR Bangalore, IIVR Varanasi \\
III & 4 & Swarna Priya, Arka Sharat, HAFB-3, Kasi & HARP, Ranchi \\
IV & 3 & Param & HAFB-1,HAFB-5,HAFB-6 Ranchi \\
V & 2 & HAFB-4, Swarna Lata & IIVR, Varanasi \\
VI & 1 & PDR-14 & IIHR Bangalore \\
VII & 1 & IIHR-4 &
\end{tabular}

pedigree method of breeding (Neelavthi and Govindarasu, 2010). Therefore, choice of the parents for hybridization should be decided on the basis of genetic diversity rather than geographic diversity (Nancee et al., 2013).

Inter cluster distance values were greater than intra-cluster distance value suggesting heterogeneous and homogeneous nature of the strains between and within the clusters respectively (Table 4). The maximum intra cluster distance value was observed for cluster I (71.76), followed by cluster IV (70.70), cluster II (67.44), cluster III (67.35), cluster V (52.25). The high intra cluster distance value in cluster I possessing maximum number of 9 genotypes indicated the presence of wide genetic diversity among the genotypes in this cluster. The diversity may be utilized for selection of
Table 4: Average intra-cluster (diagonal) and inter-cluster distance ( $\mathrm{D}^{2}$ values) among 7 clusters of 28 French bean genotypes

\begin{tabular}{lccccccc}
\hline $\begin{array}{l}\text { Clu- } \\
\text { ster }\end{array}$ & $\begin{array}{c}\text { I } \\
(9)\end{array}$ & $\begin{array}{c}\text { II } \\
(8)\end{array}$ & $\begin{array}{c}\text { III } \\
(4)\end{array}$ & $\begin{array}{c}\text { IV } \\
(3)\end{array}$ & $\begin{array}{c}\text { V } \\
(2)\end{array}$ & $\begin{array}{c}\text { VI } \\
(1)\end{array}$ & $\begin{array}{c}\text { VII } \\
(1)\end{array}$ \\
\hline I & 71.76 & 175.34 & 90.84 & 448.16 & 627.41 & 158.76 & 157.30 \\
II & & 67.44 & 248.68 & 149.60 & 544.93 & 451.54 & 372.45 \\
III & & & 67.35 & 557.37 & 712.79 & 127.29 & 140.24 \\
IV & & & & 70.70 & 624.71 & 862.56 & 751.79 \\
V & & & & & 52.25 & 623.66 & 1022.57 \\
VI & & & & & & 0.00 & 233.20 \\
VII & & & & & & & 0.00 \\
\hline
\end{tabular}

"Diagonal values indicate intra-cluster distance 
superior genotypes to produce pretty high variability.

The highest inter cluster distance value (1022.57) was observed between cluster V and VII followed by (862.56) between cluster IV and VI, (751.79) between cluster IV and VII, (712.79) between cluster III and V. On the other hand, the minimum inter cluster distance (90.84) was reported between cluster I and II, (127.29) between cluster III and VI. Based on the above studies, it could be suggested that crosses involving genotypes from divergent clusters (V and VII, IV and VI, IV and VII, III and V) are likely to exhibit high heterotic expression for yield components and wider segregation in fillial generations. The minimum inter cluster distance between I and II indicated that most of the characters had similar values in these clusters. Similar lines of observations were obtained by Govankoppa et al. (2002), Patel et al. (2011). The results also indicated that genotypes specifically from Ranchi had higher genetic distance with other genotypes. This might be due to distinctness in some morphological characters viz. number of days taken to $50 \%$ flowering, days to $1^{\text {st }}$ green pod picking, number of primary branches plant ${ }^{-1}$, number of secondary branches plant ${ }^{-1}$, green pod width, green pod breadth, number of pods plant ${ }^{-1}$, single pod weight, and pod yield plant ${ }^{-1}$.

The mean values of clusters for various characters are presented (Table 5). Almost all the clusters were highly distinct to each other with respect to all the characters. The cluster IV exhibited high pod yield plant ${ }^{-1}$ (169.44), followed by cluster II (117.74), cluster V (96.32) and so on. Cluster IV recorded high single pod weight (8.60), number of pods plant $^{-1}$ (22.6), pod breadth (1.16), green pod width (0.91), number of primary (4.97) and secondary branches plant ${ }^{-1}$ (9.48). Simultaneously, cluster IV recorded lowest days to $50 \%$ flowering (35.47), days to $1^{\text {st }}$ green pod picking (56.60).
Among other important yield contributing traits, cluster $\mathrm{V}$ recorded highest green pod length (16.12), plant height (115.02). Aiming at the ideotypic plant type, genotypes in cluster IV with less days to $50 \%$ flowering (35.47), less days to $1^{\text {st }}$ green pod picking (56.60), high single pod weight (8.60), number of pods plant ${ }^{-1}$ (22.6), pod breadth (1.16), pod yield plant ${ }^{-1}$ (169.44), green pod width (0.91), number of primary branches plant ${ }^{-1}$ (4.97) and cluster $\mathrm{V}$ with high pod length (16.12), plant height (115.02) could be used for the purpose of breeding.

An assessment of contribution of different characters towards total genetic divergence (Table 5) revealed that plant height $(20.22 \%)$ contributed highest towards total divergence followed by green pod width (14.59\%), number of secondary branches plant ${ }^{-1}(10.83 \%)$ and days to $50 \%$ flowering $(10.15 \%)$ etc. Cluster means together with information on the traits that contribute maximum towards divergence would help in selection of parents. The results imply that in order to select genetically diverse genotypes, the material should be screened for the important traits like plant height, green pod width.

The group constellations formulated on the basis of Mahalanobis's $D^{2}$ statistics were confirmed by canonical analysis. The three canonical roots were responsible for $86.6 \%$ of total variance of uncorrelated (Y variables), which indicated that the differentiation of these traits was nearly complete in these genotypes in three phases (Table 6). The relative contribution of genotypes reflected existence of parallelism between grouping obtained by $\mathrm{D}^{2}$ analysis and canonical analysis.

Based on inter-cluster distance, per se performance of genotypes in clusters and contribution of traits towards

Table 5: Cluster mean values and contribution of individual traits to divergence

\begin{tabular}{|c|c|c|c|c|c|c|c|c|c|c|c|c|c|}
\hline $\begin{array}{l}\text { Cluster/ } \\
\text { character }\end{array}$ & DFF & DFGGPP & $\begin{array}{l}\mathrm{PH} \\
(\mathrm{cm})\end{array}$ & NPBP & NSBP & $\begin{array}{l}\text { BIL } \\
(\mathrm{cm})\end{array}$ & $\begin{array}{l}\text { BID } \\
(\mathrm{cm})\end{array}$ & $\begin{array}{l}\text { GPL } \\
(\mathrm{cm})\end{array}$ & $\begin{array}{l}\text { GPW } \\
(\mathrm{cm})\end{array}$ & $\begin{array}{l}\text { GPB } \\
(\mathrm{cm}) \\
\end{array}$ & NPP & $\begin{array}{l}\text { SPW } \\
(\mathrm{g})\end{array}$ & $\begin{array}{c}\text { PYP } \\
(\mathrm{g})\end{array}$ \\
\hline I & 44.16 & 64.62 & 52.25 & 3.45 & 5.87 & 1.88 & 0.50 & 12.70 & 0.68 & 0.97 & 9.66 & 7.77 & 67.70 \\
\hline II & 39.47 & 60.27 & 62.24 & 4.14 & 7.29 & 2.11 & 0.66 & 14.80 & 0.86 & 1.04 & 17.263 & 7.91 & 117.74 \\
\hline III & 46.57 & 68.00 & 49.31 & 3.76 & 5.36 & 1.53 & 0.41 & 13.37 & 0.61 & 0.95 & 15.75 & 5.93 & 80.45 \\
\hline IV & 35.47 & 56.60 & 71.96 & 4.97 & 9.48 & 3.03 & 0.74 & 16.89 & 0.91 & 1.16 & 22.60 & 8.60 & 169.44 \\
\hline V & 54.30 & 80.31 & 115.02 & 4.17 & 6.70 & 7.19 & 0.68 & 16.12 & 0.79 & 1.05 & 13.33 & 8.16 & 96.32 \\
\hline VI & 54.24 & 76.28 & 57.04 & 3.22 & 4.48 & 1.83 & 0.38 & 10.74 & 0.55 & 1.03 & 6.98 & 7.68 & 47.75 \\
\hline VII & 44.07 & 66.70 & 35.94 & 2.95 & 4.67 & 1.22 & 0.75 & 10.43 & 0.51 & 0.87 & 0.87 & 4.67 & 44.26 \\
\hline $\mathrm{CTD}^{*}(\%)$ & 12.15 & 6.54 & 20.22 & 5.83 & 10.83 & 5.26 & 8.37 & 5.41 & 14.59 & 2.20 & 4.23 & 3.66 & 0.64 \\
\hline
\end{tabular}

${ }^{*}$ CTD: Contribution towards divergence; DFF: Days to $50 \%$ flowering; DFGGPP: Days to $1^{\text {st }}$ green pod picking; PH: Plant height; NPBP: No. of primary branches plant ${ }^{-1}$; NSBP: No. of secondary branches plant ${ }^{-1}$; BIL: Basal inter nodal length; BID: Basal internodal diameter; GPL: Green pod length; GPW: Green pod width; GPB: Green Pod breadth; NPP: No. of pods plant ${ }^{-1}$; SPW: Single pod weight; PYP: Pod yield plant ${ }^{-1}$ 
genetic divergence, the following genotypes (Table 7) were identified from each divergent cluster for inclusion in a hybridization programme. The crosses between these genotypes would produce desirable transgressive segregants in fillial generations combining all the desirable traits.

Table 6: Canonical root values, percent of variation explained and cumulative total variation for 28 genotypes of French bean

\begin{tabular}{lccc}
\hline $\begin{array}{l}\text { Canonical } \\
\text { root }\end{array}$ & $\begin{array}{c}\text { Values of } \\
\text { canonical } \\
\text { root }\end{array}$ & $\begin{array}{c}\text { Percent of } \\
\text { variation } \\
\text { explained }\end{array}$ & $\begin{array}{c}\text { Cumulative } \\
\text { total percent } \\
\text { variation }\end{array}$ \\
\hline $\mathrm{Z1}$ & 1880.33 & 52.80 & 52.80 \\
$\mathrm{Z} 2$ & 128.58 & 28.90 & 81.70 \\
$\mathrm{Z} 3$ & 174.87 & 4.90 & 86.60 \\
\hline
\end{tabular}

Table 7: Promising genotypes of French bean identified from different clusters for inclusion in the hybridization programme

\begin{tabular}{|c|c|c|}
\hline $\begin{array}{l}\text { Cluster } \\
\text { no. }\end{array}$ & Genotypes & Desirable characters \\
\hline \multirow[t]{3}{*}{ IV } & HAFB-1 & $\begin{array}{l}\text { Number of primary branches plant }{ }^{-1} \text {, } \\
\text { number of secondary branches } \\
\text { plant }{ }^{-1} \text {, green pod length, green pod } \\
\text { breadth, single pod weight, pod yield } \\
\text { plant }^{-1}\end{array}$ \\
\hline & HAFB-5 & $\begin{array}{l}\text { Days to } 50 \% \text { flowering, number of } \\
\text { pods plant }{ }^{-1} \text {, days to } 1^{\text {st }} \text { pod picking }\end{array}$ \\
\hline & HAFB-6 & Green pod width \\
\hline VI & PDR-14 & Green pod breadth \\
\hline VII & IIHR-4 & Basal intermodal diameter \\
\hline
\end{tabular}

\section{Conclusion}

Traits viz. plant height, number of pods plant ${ }^{-1}$ and number of secondary branches plant ${ }^{-1}$ would respond effectively for phenotypic selection. There was no correlation between geographic diversity and genotypic diversity. Basing on variability and divergence, the genotypes such as HAFB1, HAFB-5, HAFB-6, PDR-14, IIHR-4 may be included in hybridization programme.

\section{References}

Anonymous, 2012. NHB Database, 2011-12. National Horticulture Board. Gurgaon http://www.nhb.gov.in.

Burton, G.W., 1952. Quantitative inheritance in grasses. In: Proceedings of $6^{\text {th }}$ International Grassland Congress 1, 277-283.

Choubey, P.K., Singh, S.P., Chaubey, T., 2003. Genetic divergence in Rajmash (P. vulgaris L.). Vegetable Science 30(2), 190-191.

Evans, A.M., 1976. Evolution of crop plants. N.W. Simmonds (Ed.), Longmann, London, 168-172.

FAO, 2002. FAO Bulletin of statistics, Food and Agricultural Organisation of the United Nations, Rome, 3(2), 104.

FAOSTAT, 2008. Food and Agricultural Organisation Statistics. Available from http://www.faostat.org

Gokulakrishnan, J., Kumar, B.S., Prakash, M., 2012. Studies on genetic diversity in mung bean (Vigna radiata L.), Legume Research 35(1), 50-52.

Govanakoppa, R.B., Hosmani, R.M., Salimath, P.M., 2002. Genetic diversity in French bean under moisture stress condition. Vegetable Science 29(1), 37-39.

Johnson, H.W., Robinson, H.F., Comstock, R.E., 1955. Genotypic and phenotypic correlations in soybean and their implications in selection. Agronomy Journa 147, 477-483.

Kalia, P., Pathania, N.K., 2007. Genetic variability and trait relationships for quantitative and quality characters in winter bean (Vicia faba L.). Acta Horticulturae 752, 405-409.

Kaplan, L., 1965. Archaeology and domestication in America Phaseolus bean. Economic Botany 19, 358.

Lal, H., Rai, M., Verma, A.,Vishwanath., 2005. Analysis of genetic divergence of dolichos bean (Lablab purpureus) genotypes.Vegetable science 32(2), 129-132.

Mahalanobis, P.C., 1936. On the generalized distance in statistics, In: Proceedings of National Academy of Science, India 2, 49-55.

Murthy, B.R., Arunachalam, V., 1966. The nature of genetic divergence in relation to breeding system in crop plants. Indian journal of Genetics 26, 188-198.

Nancee., Rana, M.K., Partap, P.S., Ranjan, R., 2013. Study of genetic divergence in vegetable cowpea. Vegetable Science 40(2), 182-184.

Neelavathi, S., Govindarasu, R., 2010. Analysis of variability and Diversity in Rice Fallow Blackgram (Vigna mungo L. Hepper). Legume research 33(3), 206-210.

Nimbalkar, C.A., Baviskar, A.P., Desai, U.T., 2002. Selection strategy for yield improvement in rajmash (Phaseolus vulgaris L.). Indian Journal of Genetics and Plant Breeding 62(4), 349-351.

Pan, R.S., Singh, A.K., Rai, M., Krishna Prasad, V.S.R., Kumar, S., 2004. Genetic variation and character association in photo-insensitive dolichos bean (Lablab purpureus L. Sweet). Vegetable Science 31(1), 22-25.

Panse, V.G., Sukhatme, P.V., 1985. Statistical methods for agricultural workers. ( $4^{\text {th }}$ Edn.), ICAR, New Delhi, 389 
Patel, K.L., Sharma, G.L., Mehta, N., Sarnaik, D.A., 2011. Correlation and path analysis in Dolichos bean (Dolichos lablab L.) for Chhattisgarh Plains. Journal of Soils and Crops 21(2), 188-195.

Rai, N., Asati, B.S., Singh, A.K., Yadav, D.S., 2006. Genetic variability, character association and path coefficient study in pole type French bean. Indian Journal of Horticulture 63(2), 188-191.

Rai, N., Asati, B.S., Yadav, D.S., Singh, A.K., 2004. Genetic analysis in French bean (P. vulgaris L.). Vegetable Science 31(2), 138-141.

Rao, C.R., 1952. Advanced Statistical Methods in Biometrical Research, John Wiley and Sons, New York. Hafner Press.
Singh, S.P., 1999. Improvement of small-seeded race Mesoamerican cultivars. In: Singh, S.P., Kluwer, D. (Eds.), Common Bean Improvement in the Twenty-first Century, 225-274.

Singh, A.K., 2006. Genetic divergence in French bean ( $P$. vulgaris L.). Vegetable Science 33(1), 103-105.

Singh, B.K., Singh, B.P., Ram, H.H., 2000. Variability and correlation studies in bush type French bean (Phaseolus vulgaris L.) in relation to green pod yield. Progressive Horticulture 32(2), 176-182.

Suneetha, N., Vasanthi, R.P., Sudhakar P., Reddy, K.R., 2013. Genetic diversity analysis among released and pre released cultures in groundnut. Legume Research 36(3), 208-213. 